\title{
Closure of the Proterozoic Mozambique Ocean was instigated by a late Tonian plate reorganization event
}

\author{
Alan S. Collins ${ }^{1 *}$, Morgan L. Blades ${ }^{1}$, Andrew S. Merdith ${ }^{2}$, John D. Foden ${ }^{1}$ \\ ${ }^{1}$ Tectonics and Earth Systems (TES), Department of Earth Sciences, The University of \\ Adelaide, Adelaide, SA 5005, Australia. \\ ${ }^{2}$ UnivLyon, Université Lyon 1, Ens de Lyon, CNRS, UMR 5276 LGL-TPE, F-69622, \\ Villeurbanne, France \\ *corresponding author \\ alan.collins@adelaide.edu.au,Twitter@geoAlanC \\ morgan.blades@adelaide.edu.au, \\ andrew.merdith@univ-lyon1.fr \\ john.foden@adelaide.edu.au
}

This is a pre-print of a manuscript accepted for publication in Communications Earth \& Environment

https://www.nature.com/commsenv/ 


\section{Closure of the Proterozoic Mozambique Ocean was}

\section{2 instigated by a late Tonian plate reorganization event}

4 Alan S. Collins ${ }^{1 *}$, Morgan L. Blades ${ }^{1}$, Andrew S. Merdith ${ }^{2}$, John D. Foden ${ }^{1}$

$5{ }^{1}$ Tectonics and Earth Systems (TES), Department of Earth Sciences, The University of

6 Adelaide, Adelaide, SA 5005, Australia.

$7{ }^{2}$ UnivLyon, Université Lyon 1, Ens de Lyon, CNRS, UMR 5276 LGL-TPE, F-69622,

8 Villeurbanne, France

9 *corresponding author

10 alan.collins@adelaide.edu.au,

11 morgan.blades@adelaide.edu.au,

12 andrew.merdith@univ-lyon1.fr

13 john.foden@adelaide.edu.au

\section{ABSTRACT}

Plate reorganization events involve fundamental changes in lithospheric plate-motions and can influence the lithosphere-mantle system as well as both ocean and atmospheric circulation through bathymetric and topographic changes. Here, we compile published data to interpret the geological record of the Neoproterozoic Arabian-Nubian Shield and integrate this with a full-plate tectonic reconstruction. Our model reveals a plate reorganization event in the late Tonian period about 720 million years ago that changed plate-movement directions in the Mozambique Ocean. After the reorganization, Neoproterozoic India moved towards both the African cratons and Australia-Mawson and instigated the future amalgamation of central Gondwana about 200 million years later. This plate kinematic change is coeval with the break-up of the core of Rodinia between Australia-Mawson and Laurentia and Kalahari and Congo. We suggest the plate reorganization event caused the long-term shift of continents to the southern hemisphere and created a pan-northern hemisphere ocean in the Ediacaran.

\section{INTRODUCTION}

31 Plate tectonics is characterized by periods of gradual, broadly continuous, plate movement

32 that are punctuated by relatively short times of plate reorganization ${ }^{1,2}$. These are due to the 33 consumption of an oceanic plate, the collision of two continents, the cessation of subduction, 
34 or the break-up of a (super)continent ${ }^{3,4}$. These events disturb the plate kinematic status quo

35 and force adjustments over the planet surface that affect ocean and atmospheric circulation 36 and have been linked to perturbations in the carbon cycle ${ }^{5}$, amongst other things. Identifying 37 and understanding plate reorganization events in deep time is only possible with full-plate topological reconstructions. These are well developed for the Mesozoic and younger ${ }^{6}$, but have only recently been proposed for the Palaeozoic ${ }^{7,8}$ and now Neoproterozoic eras ${ }^{9,10}$.

40 These allow regional plate-tectonic induced phenomena to be understood in a global context.

41 Here we present an updated GPlates (www.gplates.org) model that uses recently published 42 geological data from the terranes of the Arabian Nubian Shield (ANS). By adding in 43 geological data from relic volcanic arcs into these full-plate topological reconstructions of the 44 ancient earth, we provide a new interpretation of the oceanic plate kinematic and dynamic 45 evolution of the Neoproterozoic Mozambique Ocean. This led to the southward journey of 46 Neoproterozoic India to collide against African Gondwana and the Australia-Mawson 47 continent ${ }^{11}$ to form the kernel of Gondwana. This plate reorganization is coeval with the 48 opening of the Pacific Basin ${ }^{12,13}$ and directly precedes the cataclysmic climatic perturbations 49 of the Cryogenian.

\section{BACKGROUND}

52 Plate tectonics has been causally linked to the Cryogenian climate instability ${ }^{14-16}$, to the 53 coeval Neoproterozoic Oxygenation Event ${ }^{17,18}$, to the biosphere tumult that included the 54 ecological takeover of eukaryote cells ${ }^{19,20}$ and, ultimately, to the evolution of metazoans ${ }^{21,22}$.

55 The veracity of these hypotheses requires knowledge of the plate tectonic configuration and 56 kinematics through the Neoproterozoic, which is missing, as most attempted reconstructions 57 are 'continental-drift' models with no full-plate circuit attempted ${ }^{11,23}$. A first attempt at a 58 full-plate topological model for 1000-520 Ma was recently published ${ }^{9}$. However, this model 59 focused predominantly on cratonic crust that had available palaeomagnetic data, and 60 consequently simplified many complex areas around Neoproterozoic active margins. Mallard 61 et al. ${ }^{24}$ demonstrated that active margins control plate size and number, therefore also control 62 many of the parameters needed to understand the role of plate tectonics on broader earth 63 systems. The ANS was an active margin and one of these areas simplified in Merdith et al. 9 , 64 yet, it is one of the most critical for Neoproterozoic plate reconstructions as it is one of the 65 most extensive areas of new Neoproterozoic crust on the planet ${ }^{25}$ (Fig. 1) and preserves 66 evidence of subduction from pre-1 Ga until the Ediacaran ${ }^{26}$. 
68 The end of the Proterozoic eon is marked by some of the most dramatic events in Earth's 69 history, with this period of time being characterised by extensive changes in seawater 70 chemistry demonstrated through the strontium, sulfur and carbon isotope records, large 71 climatic extremes, and preservation of the Ediacaran faunal assemblage and the explosion of 72 Cambrian fauna ${ }^{27}$. These global variations are concurrent with the amalgamation of 73 Gondwana, and the closure of the Mozambique Ocean; representing one of the major and 74 final Gondwana forming collisional zones ${ }^{28}$. As no in-situ oceanic crust exists before ca. 200 75 Ma, the remnants of this major ocean gateway are only preserved in relic arc-arc, arc76 continent and continent-continent collisional zones, within the East African Orogen (EAO).

77 The EAO is one of the largest orogens of the last billion years, which, in a reconstructed 78 Gondwana, extends from Turkey and the Levant, in the north to Mozambique, Madagascar, 79 Sri Lanka and East Antarctica in the south ${ }^{29}$. Along strike, the orogen is divided into two. 80 The Mozambique Belt lies in the south and is a tract of largely older continental crust, 81 extensively deformed and metamorphosed in the Neoproterozoic/Cambrian ${ }^{30}$. The ANS 82 makes up the north of the orogen ${ }^{26}$. The ANS, and adjacent Gondwanan rocks in North 83 Africa and from east Arabia to NW India preserve the evidence we use to reconstruct the 84 plate tectonic circuit as Neoproterozoic India converged and finally collided with the African 85 parts of Gondwana ${ }^{26}$.

\section{RESULTS AND DISCUSSION}

88

\section{MODEL CONTRAINTS}

90 In this paper, we use previously published geological data to constrain our full-plate 91 topological model for the evolution and closure of the Mozambique Ocean and the 92 amalgamation of central Gondwana. The full-plate model is based on geological and 93 paleomagnetic data and is part of the first published self-consistent model of global plate 94 tectonics over the last billion years ${ }^{10}$. We emphasize that this is a model, and although we 95 argue that it is best represents the geological and paleomagnetic data available in 2021, it is 96 not a unique solution and is subject to improvement with more data and better interpretations.

97 The model, however, does present interesting implications for the progression of plate 98 tectonics over this time, the distribution of plates, of continents and oceans and leads to 99 hypotheses for plate-tectonic influence of earth-surface systems that we begin to explore in 100 this paper. 
101 The ANS is laced with suture zones that represent collisions between different terranes as subduction zones consumed the intervening oceanic crust (Fig. 1). A dramatic feature of the region is that pre-715 Ma sutures are aligned approximately ninety degrees from post-715 Ma sutures ${ }^{26,31}$. This observation reflects a major change in plate convergence direction and we use this as the start of a higher-order reconstruction of this region in a full-plate context.

\section{The Mozambique Ocean, Azania and Afif-Abas}

107 The Mozambique Ocean closed as Neoproterozoic India converged on the African parts of Gondwana (Kalahari, Congo, Sahara) to form central Gondwana ${ }^{29}$. The East African Orogen resulted from the collision between these major continents and amalgams of smaller terranes, during the Neoproterozoic to early Cambrian. Sandwiched within the EAO lies a broad band

111 of Archean to Paleoproterozoic crust that was identified by Collins and Windley ${ }^{32}$ as a 112 microcontinent (subsequently named 'Azania'), whose remains are found in southern India, 113 central Madagascar, Somalia, eastern Ethiopia and Arabia (Fig. 1). In Yemen, the Al-Mafid 114 Terrane is correlated with Azania ${ }^{32}$ and this is separated from a second pre-Neoproterozoic 115 terrane called the Abas Terrane by a Neoproterozoic arc terrane (the Al Bayda terrane). 116 Because of this, Collins and Windley ${ }^{32}$ suggested that a second microcontinent existed that 117 they called Afif-Abas due to the continuation of the Abas terrane into Saudi Arabia as the 118 Afif Terrane. Azania, and Afif-Abas, are interpreted to have collided with the eastern margins of the Congo 121 craton and Saharan Metacraton by approximately 630 Ma to form the East African Orogeny 122 sensu stricto. A younger orogeny (ca. 570-520 Ma), was interpreted to represent the final 123 collision between India and the amalgamated Africa/Arabia and called the Malagasy orogeny 124 11.

\section{The Eastern Margin of the EAO (NW India to Oman)}

127 The easternmost margin of the northern East African Orogen is the boundary between the 128 Mesoproterozoic terranes of India and the Stenian-Tonian crust that extents west from the 129 Delhi-Aravalli Orogen. This has been interpreted to be the eastern margin of the northern 130 East African Orogen. During the Stenian and Tonian, progressive arc accretion of volcanic 131 arc rocks onto the NW margin of Neoproterozoic India occurred; extending into the basement 132 rocks of Pakistan and the inliers of Oman ${ }^{33,34}$. This was later covered by an extensive 133 Cryogenian-Ediacaran passive margin succession, with comparable sequences continuing 134 into the Cambrian ${ }^{35}$. 


\section{The Arabian Nubian Shield}

137 The ANS is dominated by low grade volcano-sedimentary sequences and associated plutonic 138 and ophiolitic remnants. The tectonic history of the ANS is complicated and preserves a 139 complex mix of terranes, accreted arcs that record subduction polarity reversals that are

140 reviewed and summarised in a number of papers ${ }^{26,31}$. There are no reliable paleomagnetic 141 data available to constrain these blocks, so we have constrained their positions by their 142 relation to each other and through plate kinematic constraints.

144 The oldest terrane in the ANS is the late Mesoproterozoic Sa'al Metamorphic complex (1.03$1451.02 \mathrm{Ga}$ ) in Sinai, marking the initiation of magmatism in the northern-most ANS ${ }^{36,37}$ (Fig. 146 1). The location of this Stenian terrane in the reconstruction is uncertain, but coeval 147 subduction-magmatism occurred within the Saharan Metacraton (see below).

149 The Tonian to Cryogenian history of the ANS is marked by formation of oceanic volcanic 150 arcs and continental volcanic arcs built on Azanian (or Afif-Abas) crust that amalgamated to 151 form a larger intra-Mozambique ocean terrane separate from both Neoproterozoic India and 152 African Gondwanan continents. A number of terranes in the ANS are correlated as 153 equivalents, separated by the opening of the Red Sea, from south to north, these are the Asir 154 and Tokar/Barka terranes, the Haya and Jiddah terranes, the Hijaz and Gabgaba/Gebeit 155 terranes, and the Eastern Desert and Midyan terranes ${ }^{26}$. It is unclear whether the combined 156 Asir-Tokar/Barka terrane and Haya-Jiddah terranes were ever on separate plates as, in Saudi 157 Arabia, no clear suture is seen between them. In SE Sudan and Eritrea, the Barka suture does 158 appear as the site of ocean closure, so these may form a complex middle Tonian amalgam.

160 The older, Tonian to earliest Cryogenian, amalgamation history of the ANS is marked by 161 approximately ENE-WSW oriented sutures (present orientation) between juvenile 162 Neoproterozoic ocean-arc terranes. The oldest of these sutures is between the Jiddah-Haya 163 and Gabgaba/Gebeit-Hijaz terranes (the Bi'r Umq-Nakasib suture), which is dated at ca. $164780-750 \mathrm{Ma}^{26}$. This suture created the kernel of a late Tonian microcontinent. The Midyan165 Eastern Desert collided with this kernel ca. 715 Ma along the Yanbu-Sol Hamed suture ${ }^{31}$. 166 Both of these sutures evolved from SE-dipping subduction zones ${ }^{31}$. 
168 The older ENE-WSW sutures are bound by younger NNW-SSE Cryogenian to Ediacaran sutures and terranes that represent a fundamental kinematic change in Mozambique Ocean subduction. The oldest of these is the 680-640 Ma Nabitah suture, which forms the eastern margin of the intra-Mozambique Ocean island-arc terrane microcontinent (discussed above), against Tonian-Cryogenian continental arcs built on the Afif-Abas microcontinent. This now enlarged Cryogenian Afif-Abas microcontinent collided with the active margin of the Sahara Metacraton along the Sudanese Keraf Suture. This collision occurred in late Cryogenian to early Ediacaran times (ca. 650-580 Ma) ${ }^{38}$. Further to the east, in the most easterly exposed terrane, the Saudi Ar Rayn Terrane, juvenile calc-alkaline magmatism stretches from ca. 690 Ma to $615 \mathrm{Ma}^{39}$. Turbiditic sediment deposition in the Ad Dawadimi basin that separates the Ar Rayn Terrane from the Afif-Abas microcontinent continued until at least $620 \mathrm{Ma}$, but was locally intruded by ca. 630 Ma adakitic magmas ${ }^{40}$. This sequence was metamorphosed to greenschist-facies grades at ca. $620 \mathrm{Ma}{ }^{41}$. Further east still, broad N-S magnetic highs, beneath the Arabian Phanerozoic sedimentary sequence ${ }^{42}$, suggest younger arc terranes now buried beneath the Rub al-Khali Basin. The transition to post-tectonic magmatism within the eastern terranes of the ANS begins from $605 \mathrm{Ma}^{39}$ and pull-apart basins developed along the large strike-slip faults that cut the region ${ }^{43}$. Post-tectonic magmatism begins in western Ethiopia at ca. $572 \mathrm{Ma}^{44}$.

187 The final collision between Neoproterozoic India and the, by then amalgamated, 188 Azania/Congo Craton occurred at ca. 570-540 Ma, closing the final strand of the 189 Mozambique Ocean ${ }^{11,28}$. This suture lies beneath the Phanerozoic cover between the exposed 190 Saudi and Yemen basement and Mirbat in SW Oman. It appears to be imaged by shear-wave 191 anisotropy variations seen directly west of Mirbat ${ }^{45}$. In western Oman, latest Ediacaran192 Cambrian deformation is seen in the subsurface, its limit is known as the Western 193 Deformation Front and the deformation associated with this is known as the 'Angudan event'. 194 The sub-Rub al-Khali suture has been traced south within reconstructed Gondwana to 195 Madagascar where it has been correlated with the Antsaba shear zone of NW Madagascar ${ }^{46}$, 196 the Betsimisaraka suture ${ }^{32}$ and into the Palghat-Cauvery Suture of southern India ${ }^{47}$. This 197 Palghat-Betsimisaraka-Antsaba-Western Deformation Front suture represents the final 198 suture of the Mozambique Ocean ${ }^{9,11}$.

\section{The Western Margin of the EAO (the eastern Saharan Metacraton)}


201 The Saharan Metacraton is still very poorly known, but extensive late Mesoproterozoic

202 subduction-related magmatism is found in Chad and west and north Sudan ${ }^{48}$. To the west of 203 this, in eastern Sudan and western Ethiopia magmatism associated with early Neoproterozoic 204 subduction characterizes terranes that are thought to have formed over westward dipping 205 subduction zones ${ }^{44,49}$. This longevity of subduction, which also includes that seen in the 206 Sinai ${ }^{36,37}$, demonstrates that the EAO extends back into the Stenian, or even earlier, when 207 terrane accretion and subduction-zone magmatism initiated against the Paleoproterozoic 208 kernel of the 'metacraton'. The NE margin of the Congo Craton, in Uganda, preserves 209 orogenesis that begins with Tonian subduction-zone magmatism in the Karamoja Belt that is 210 coeval with terranes in Sudan ${ }^{50}$.

211

\section{A LATE TONIAN PLATE RECONFIGURATION}

213

214 The model presented here (Fig. 2) is developed from the reconstruction of Merdith et al. ${ }^{9}$.

215 Details of both geological and paleomagnetic data used to constrain cratonic configurations, 216 positions and motions are provided therein. Here, data and observations discussed above for 217 the terranes of northern Africa, Arabia and NW India have been integrated ${ }^{10}$. These define a 218 marked change in Mozambique Ocean subduction kinematics at ca. 720 Ma, from a 219 predominately N-S to E-W striking subduction system (Fig. 2). The timing of these observed 220 changes are broadly coeval with the start of Neoproterozoic India's southern progression 221 from polar regions to lower latitudes ${ }^{29,51,52}$ and we suggest that they represent a plate 222 reorganization in this hemisphere. This kinematic shift is coeval with sedimentological and 223 kinematic estimates for the breakup of the core of Rodinia. The ancestral Pacific basin is 224 constrained to open before 725 Ma based on kinematic constraints ${ }^{12}$ and separation of the 225 Kalahari and Congo continents is also consistent with voluminous magmatism along the 226 southern Congo margin at ca. $750 \mathrm{Ma}^{53}$. This late Tonian plate reorganization heralds the 227 start of a shift of continental crust away from the northern hemisphere into the southern 228 hemisphere (Figs. 2 and 3). This narrows, then eventually closes the equatorial Mozambique 229 Ocean. The model implies that most continental blocks were concentrated in the southern 230 hemisphere in the Late Neoproterozoic (Fig. 3). If this reflects the real distribution, then it 231 would have interesting consequences for ocean/atmosphere circulation. One possible effect 232 would be to compartmentalize ocean gyres in the southern hemisphere, while removing 233 obstacles for hemispherical circulation in the northern hemisphere (Fig. 2). This shift from bi234 hemisphere continent distribution towards a world with a pan-northern hemisphere ocean and 
235 continents concentrated in the southern hemisphere coincides with end of whole-earth

236 glaciations that characterize the middle Neoproterozoic. In contrast to the Sturtian and 237 Marinoan whole-earth glaciations, Ediacaran glaciations, such as the Gaskiers glaciation, 238 appear more regional in scale ${ }^{15,54}$. Williams and Schmidt ${ }^{55}$ hypothesized that the mid239 Ediacaran Shuram/Wonoka negative carbon isotope anomaly represents an unprecedented 240 perturbation of the world ocean. We speculate that the plate tectonic driven bifurcation of the 241 planet into continent and ocean latitudinal hemispheres may be a major control on this 242 oceanic perturbation and climate switch-a consequence of the late Tonian plate 243 reorganization.

\section{ACKNOWLEDGMENTS}

246 ASC is supported by Australian Research Council grants FT120100340 and with MLB and 247 JDF are funded by LP160101353, with the support of the Northern Territory Geological 248 Survey, Origin Energy, Santos Ltd and Imperial Oil and Gas. ASM is supported by the Deep

249 Energy Community of the Deep Carbon Observatory. We thank Anthony Pivarunas and an 250 anonymous reviewer who improved the manuscript.

\section{METHODS}

253 This manuscript is based on a full-plate tectonic reconstruction of the last billion years that 254 has been developed on the open access software GPlates (www.gplates.org). All GPlates files 255 needed to reconstruct the model are available here-https://zenodo.org/record/3647901. The 256 methodology for constructing full-plate tectonic reconstructions are detailed in Merdith et al.

$257{ }^{10}$ and also in Domeier and Torsvik ${ }^{56}$. Computation of latitudinal surface area was done using 258 pyGplates (www.pygplates.org). To extract the latitudinal distribution of continent area, we 259 first created a global equal-area mesh. We then used a grid-intersection between the nodes of 260 the mesh and the polygons of the plate model that represent continental crust to estimate the 261 area of crust at each latitude. These were summed for each timestep to create an array from 1000-520 Ma of the latitudinal distribution of crust on the earth

\section{DATA AVAILABILITY}

265 Data derived from the full-plate reconstructions used here to evaluate the latitudinal

266 distribution of continental crust through time are publically available at

267 https://github.com/amer7632/Collins_2021_Geology_palaeolat 
270 The code used to calculate and construct Figure 3 it is available here:

https://github.com/amer7632/Collins_2021_Geology_palaeolat

272

\section{REFERENCES}

Gordon, R. G. \& Jurdy, D. M. Cenozoic Global Plate Motions. J Geophys Res-Solid

276

277

278

279

280

281

282

283

284

285

286 91, 2389-2406, doi:DOI 10.1029/JB091iB12p12389 (1986).

2 Muller, R. D. et al. Ocean Basin Evolution and Global-Scale Plate Reorganization Events Since Pangea Breakup. Annual Review of Earth and Planetary Sciences 44, 107-138, doi:10.1146/annurev-earth-060115-012211 (2016).

3 Austermann, J. et al. Quantifying the forces needed for the rapid change of Pacific plate motion at 6 Ma. Earth and Planetary Science Letters 307, 289-297, doi:10.1016/j.epsl.2011.04.043 (2011).

4 Whittaker, J. M. et al. Major Australian-Antarctic plate reorganization at HawaiianEmperor bend time. Science 318, 83-86, doi:10.1126/science.1143769 (2007).

5 Louis-Schmid, B. et al. Detailed record of the mid-Oxfordian (Late Jurassic) positive carbon-isotope excursion in two hemipelagic sections (France and Switzerland): A plate tectonic trigger? Palaeogeography Palaeoclimatology Palaeoecology 248, 459472, doi:10.1016/j.palaeo.2007.01.001 (2007).

6 Muller, R. D. et al. A Global Plate Model Including Lithospheric Deformation Along Major Rifts and Orogens Since the Triassic. Tectonics 38, 1884-1907, doi:10.1029/2018tc005462 (2019).

7 Domeier, M. A plate tectonic scenario for the Iapetus and Rheic oceans. Gondwana Research 36, 275-295, doi:10.1016/j.gr.2015.08.003 (2016).

8 Domeier, M. \& Torsvik, T. H. Plate tectonics in the late Paleozoic. Geoscience Frontiers 5, 303-350, doi:10.1016/j.gsf.2014.01.002 (2014).

9 Merdith, A. S. et al. A full-plate global reconstruction of the Neoproterozoic. Gondwana Research 50, 84-134, doi:10.1016/j.gr.2017.04.001 (2017).

10 Merdith, A. S. et al. Extending full-plate tectonic models into deep time: Linking the Neoproterozoic and the Phanerozoic. Earth-Science Reviews 214, 103477, doi:https://doi.org/10.1016/j.earscirev.2020.103477 (2021).

11 Collins, A. \& Pisarevsky, S. Amalgamating eastern Gondwana: The evolution of the Circum-Indian Orogens. Earth-Science Reviews 71, 229-270, doi:10.1016/j.earscirev.2005.02.004 (2005).

12 Merdith, A. S., Williams, S. E., Muller, R. D. \& Collins, A. S. Kinematic constraints on the Rodinia to Gondwana transition. Precambrian Research 299, 132-150, doi:10.1016/j.precamres.2017.07.013 (2017).

13 Lloyd, J. C. et al. Neoproterozoic geochronology and provenance of the Adelaide Superbasin. Precambrian Research 350, 105849, doi:10.1016/j.precamres.2020.105849 (2020).

14 Gernon, T. M., Hincks, T. K., Tyrrell, T., Rohling, E. J. \& Palmer, M. R. Snowball Earth ocean chemistry driven by extensive ridge volcanism during Rodinia breakup. Nature Geoscience 9, 242-U283, doi:10.1038/Ngeo2632 (2016). Hoffman, P. F. et al. Snowball Earth climate dynamics and Cryogenian geologygeobiology. Sci Adv 3, e1600983, doi:10.1126/sciadv.1600983 (2017). 
31516 Sobolev, S. V. \& Brown, M. Surface erosion events controlled the evolution of plate tectonics on Earth. Nature 570, 52-+, doi:10.1038/s41586-019-1258-4 (2019).

17 Li, C., Cheng, M., Zhu, M. \& Lyons, T. W. Heterogeneous and dynamic marine shelf oxygenation and coupled early animal evolution. Emerging Topics in Life Sciences 2, 279-288, doi:https://doi.org/10.1042/ETLS20170157 (2018).

18 Williams, J. J., Mills, B. J. W. \& Lenton, T. M. A tectonically driven Ediacaran oxygenation event. Nat Commun 10, 2690, doi:10.1038/s41467-019-10286-x (2019).

19 Lenton, T. M., Boyle, R. A., Poulton, S. W., Shields-Zhou, G. A. \& Butterfield, N. J. Co-evolution of eukaryotes and ocean oxygenation in the Neoproterozoic era. Nature Geoscience 7, 257-265, doi:10.1038/ngeo2108 (2014).

20 Brocks, J. J. et al. The rise of algae in Cryogenian oceans and the emergence of animals. Nature 548, 578-+, doi:10.1038/nature23457 (2017).

21 Sahoo, S. K. et al. Ocean oxygenation in the wake of the Marinoan glaciation. Nature 489, 546-549, doi:10.1038/nature11445 (2012).

22 McKenzie, N. R., Hughes, N. C., Gill, B. C. \& Myrow, P. M. Plate tectonic influences on Neoproterozoic-early Paleozoic climate and animal evolution. Geology 42, 127130, doi:10.1130/G34962.1 (2014).

$23 \mathrm{Li}, \mathrm{Z}$. X. et al. Assembly, configuration, and break-up history of Rodinia: A synthesis. Precambrian Research 160, 179-210, doi:10.1016/j.precamres.2007.04.021 (2008).

24 Mallard, C., Coltice, N., Seton, M., Muller, R. D. \& Tackley, P. J. Subduction controls the distribution and fragmentation of Earth's tectonic plates. Nature 535, 140 + , doi:10.1038/nature17992 (2016).

25 Stern, R. A. Crustal evolution in the East African Orogen: a neodymian isotopic perspective. Journal Of African Earth Sciences 34, 109-117 (2002).

26 Johnson, P. R. et al. Late Cryogenian-Ediacaran history of the Arabian-Nubian Shield: A review of depositional, plutonic, structural, and tectonic events in the closing stages of the northern East African Orogen. Journal of African Earth Sciences 61, 167-232, doi:10.1016/j.jafrearsci.2011.07.003 (2011).

27 Halverson, G. P., Hurtgen, M., Porter, S. M. \& Collins, A. S. in Events at the Precambrian-Cambrian boundary: a focus on southwestern Gondwana (eds C. Gaucher, A. Sial, G.P Halverson, \& H. Frimmel) (Elsevier, Developments in Precambrian Geology, 2010).

28 Schmitt, R. d. S., Fragoso, R. d. A. \& Collins, A. S. in Geology of Southwest Gondwana (eds Siegfried Siegesmund, Miguel A. S. Basei, Pedro Oyhantçabal, \& Sebastian Oriolo) 411-432 (Springer International Publishing, 2018).

29 Meert, J. G. A synopsis of events related to the assembly of eastern Gondwana. Tectonophysics 362, 1-40 (2003).

30 Fritz, H. et al. Orogen styles in the East Africa Orogens: A review of the Neoproterozoic to Cambrian Tectonic Evolution. Journal of African Earth Sciences 86, 65-106 (2013).

31 Robinson, F. A., Foden, J. D. \& Collins, A. S. Geochemical and isotopic constraints on island arc, synorogenic, post-orogenic and anorogenic granitoids in the Arabian Shield, Saudi Arabia. Lithos 220, 97-115, doi:10.1016/j.lithos.2015.01.021 (2015).

32 Collins, A. \& Windley, B. The tectonic evolution of central and northern Madagascar and its place in the final assembly of Gondwana. Journal of Geology 110, 325-339, doi:10.1086/339535 (2002).

33 Alessio, B. L. et al. Origin and tectonic evolution of the NE basement of Oman: a window into the Neoproterozoic accretionary growth of India? Geological Magazine 155, 1150-1174, doi:10.1017/S0016756817000061 (2018). 
34 Blades, M. L. et al. Unravelling the Neoproterozoic accretionary history of Oman, using an array of isotopic systems in zircon. Journal of the Geological Society, jgs2018-2125, doi:10.1144/jgs2018-125 (2019).

35 Cozzi, A., Rea, G. \& Craig, J. From global geology to hydrocarbon exploration: Ediacaran-Early Cambrian petroleum plays of India, Pakistan and Oman. Geological Society, London, Special Publications 366, 131-162, doi:10.1144/sp366.14 (2012).

36 Be'eri-Shlevin, Y., Eyal, M., Eyal, Y., Whitehouse, M. J. \& Litvinovsky, B. The Sa'al volcano-sedimentary complex (Sinai, Egypt): A latest Mesoproterozoic volcanic arc in the northern Arabian Nubian Shield. Geology 40, 403-406, doi:10.1130/G32788.1 (2012).

37 Eyal, M., Be'eri-Shlevin, Y., Eyal, Y., Whitehouse, M. J. \& Litvinovsky, B. Three successive Proterozoic island arcs in the Northern Arabian-Nubian Shield: Evidence from SIMS U-Pb dating of zircon. Gondwana Research 25, 338-357, doi:10.1016/j.gr.2013.03.016 (2014).

38 Abdelsalam, M. G. et al. The Neoproterozoic Keraf Suture in NE Sudan: sinistral transpression along the eastern margin of West Gondwana. Journal of Geology 106, 133-147 (1998).

39 Doebrich, J. L. et al. Geology and metalogeny of the Ar Rayn terrane, eastern Arabian shield: Evolution of a Neoproterozoic continental-margin arc during assembly of Gondwana within the East African orogen. Precambrian Research 158, 17-50 (2007).

40 Cox, G. M., Foden, J. \& Collins, A. S. Late Neoproterozoic adakitic magmatism of the eastern Arabian Nubian Shield. Geoscience Frontiers 10, 1981-1992, doi:10.1016/j.gsf.2017.12.006 (2019).

41 Cox, G. M. et al. Ediacaran terrane accretion within the Arabian-Nubian Shield. Gondwana Research 21, 341-352, doi:10.1016/j.gr.2011.02.011 (2012).

42 Johnson, P. R. \& Stewart, I. C. F. Magnetically inferred basement structure in central Saudi Arabia. Tectonophyscics 245, 37-52 (1995).

43 Nettle, D. et al. A middle-late Ediacaran volcano-sedimentary record from the eastern Arabian-Nubian shield. Terra Nova 26, 120-129, doi:10.1111/ter.12077 (2014).

44 Blades, M. L. et al. Age and hafnium isotopic evolution of the Didesa and Kemashi Domains, western Ethiopia. Precambrian Research 270, 267-284, doi:10.1016/j.precamres.2015.09.018 (2015).

45 Al-Lazki, A. et al. Upper mantle anisotropy of southeast Arabia passive margin [Gulf of Aden northern conjugate margin], Oman. Arab J Geosci 5, 925-934, doi:10.1007/s12517-011-0477-2 (2012).

46 Armistead, S. E. et al. Evolving Marginal Terranes During Neoproterozoic Supercontinent Reorganization: Constraints From the Bemarivo Domain in Northern Madagascar. Tectonics 38, 2019-2035, doi:10.1029/2018tc005384 (2019).

47 Collins, A. S. et al. Passage through India: the Mozambique Ocean suture, highpressure granulites and the Palghat-Cauvery shear zone system. Terra Nova 19, 141147, doi:10.1111/j.1365-3121.2007.00729.x (2007).

48 de Wit, M. J. \& Linol, B. in Geology and Resource Potential of the Congo Basin (eds Maarten J. de Wit, François Guillocheau, \& Michiel C. J. de Wit) 19-37 (Springer Berlin Heidelberg, 2015).

49 Blades, M. L., Foden, J., Collins, A. S., Alemu, T. \& Woldetinsae, G. The origin of the ultramafic rocks of the Tulu Dimtu Belt, western Ethiopia - do they represent remnants of the Mozambique Ocean? Geological Magazine 156, 62-82, doi:10.1017/S0016756817000802 (2019). 
41250 Westerhof, A. B. P. et al. Geology and Geodynamic Development of Uganda with

413 Explanation of the 1:1,000,000 Scale Geological Map. 387 (Geological Survey of

$414 \quad$ Finland, 2014).

$41551 \quad$ Meert, J. G. et al. Precambrian crustal evolution of Peninsular India: A 3.0 billion

416

417

418

419

420

421

422

423

424

425

426

427

428

429

430

431

432

433

434

435

436

437

438

\section{FIGURE CAPTIONS}

439

$440 \quad$ Figure 1: Map of present northern Indian Ocean region.

441 Legend: Showing the distribution of juvenile Stenian-Ediacaran crust, pre-Stenian exposed

442 crust, pre-Stenian exposed crust reworked thermally and structurally during the

443 Neoproterozoic, and Proterozoic sedimentary basins in NE Africa, Arabia and the Indian

444 subcontinent. The late Tonian plate reconfiguration is represented by the notable change from

445 pre-720 Ma, approximately NE-SW sutures to post-720 Ma, approximately NNW-SSE

446 striking sutures. MB = Mozambique Belt, NED = Northern Eastern Desert, CED = Central

447 Eastern Desert, SED = South Eastern Desert.

449 Figure 2: Global full-plate topological reconstructions.

450 Legend: a) $800 \mathrm{Ma}$, b) $750 \mathrm{Ma}$, c) $700 \mathrm{Ma}$, d) $600 \mathrm{Ma}$ modified from Merdith et al. 9,10,

451 focusing on detail within the ANS. A-A = Afif-Abas, Am = Amazonia, ANS = Arabian-

452 Nubian Shield terrane, $\mathrm{Az}=$ Azania, $\mathrm{Ba}=$ Baltic, $\mathrm{Bo}=$ Borborema, $\mathrm{Bu}=$ Butana, $\mathrm{C}=$ Congo,

$453 \mathrm{Ca}=$ Cathaysia, $\mathrm{Ch}=$ Chortis, $\mathrm{DML}=$ Dronning Maud Land, $\mathrm{G}=$ Greenland, $\mathrm{H}=$ Hoggar, $\mathrm{I}$ 
$454=$ Neoproterozoic India, $\mathrm{K}=$ Kalahari, $\mathrm{L}=$ Laurentia, Ma $=$ Mawson, NAC $=$ North

455 Australian Craton, N-B = Nigeria-Benin, NC = North China, $\mathrm{O}=$ Oman, $\mathrm{Pp}=$ Paranapanema,

$456 \mathrm{R}=$ Rayner, RDLP = Rio de la Plata, $\mathrm{S}=$ Seychelles, $\mathrm{SM}=$ Sahara Metacraton, $\mathrm{SF}=\mathrm{Sa}$ õ

457 Francisco, SMC = Sa’al Metamorphic Complex, $\mathrm{Sr}=$ Sri Lanka, Si $=$ Siberia, SAC = South

458 Australian/West Australian Craton, SES = South Ethiopian Shield, $\mathrm{Ta}=$ Tarim, WAC $=$ West

459 African Craton, WES = West Ethiopian Shield, Yg = Yangtze. Colours refer to modern

460 continents that the terranes now make up: Red = Asia, Blue = Africa, Gold $=$ South America,

461 Green $=$ Europe, Yellow $=$ North America, Purple $=$ Australia, Teal $=$ Antarctica, Lilac $=$

462 India, Madagascar and eastern Arabia. Blue dashed lines indicate schematic ocean currents.

463

$464 \quad$ Figure 3: Latitudinal distribution of continental crust with respect to time.

465 Legend: a) Percentage of continental crust in either hemisphere as a function of time. Sturtian 466 717-663 Ma, ${ }^{57,58}$, Marinoan 645-635 Ma, ${ }^{15}$ and Gaskiers $579 \mathrm{Ma},{ }^{54}$ glacial durations

467 indicated. b) Histograms of latitudinal distribution of continental area with respect to time

468 (Ma). Both as implied in Merdith et al. ${ }^{10}$. If these models reflect reality, the late Tonian sees

469 the beginning of a long-term trend in continental crust moving to southern latitudes, first into

470 tropical regions through the Cryogenian, promoting a high albedo world. The Ediacaran sees

471 a shift to lower latitudes, which would suppress albedo. $\mathrm{C}=$ Cambrian.

472

473

474

475

476

477

478

479

480

481 The authors declare no competing interests

A.S.C., M.L.B. and J.D.F conceived of and initiated the project. A.S.M. built the full-plate reconstruction. A.S.C. and M.L.B. co-wrote the first draft of the paper. M.L.B. and A.S.M. interpreted the data. All authors edited, revised and reviewed the manuscript.

COMPETETING INTERESTS 


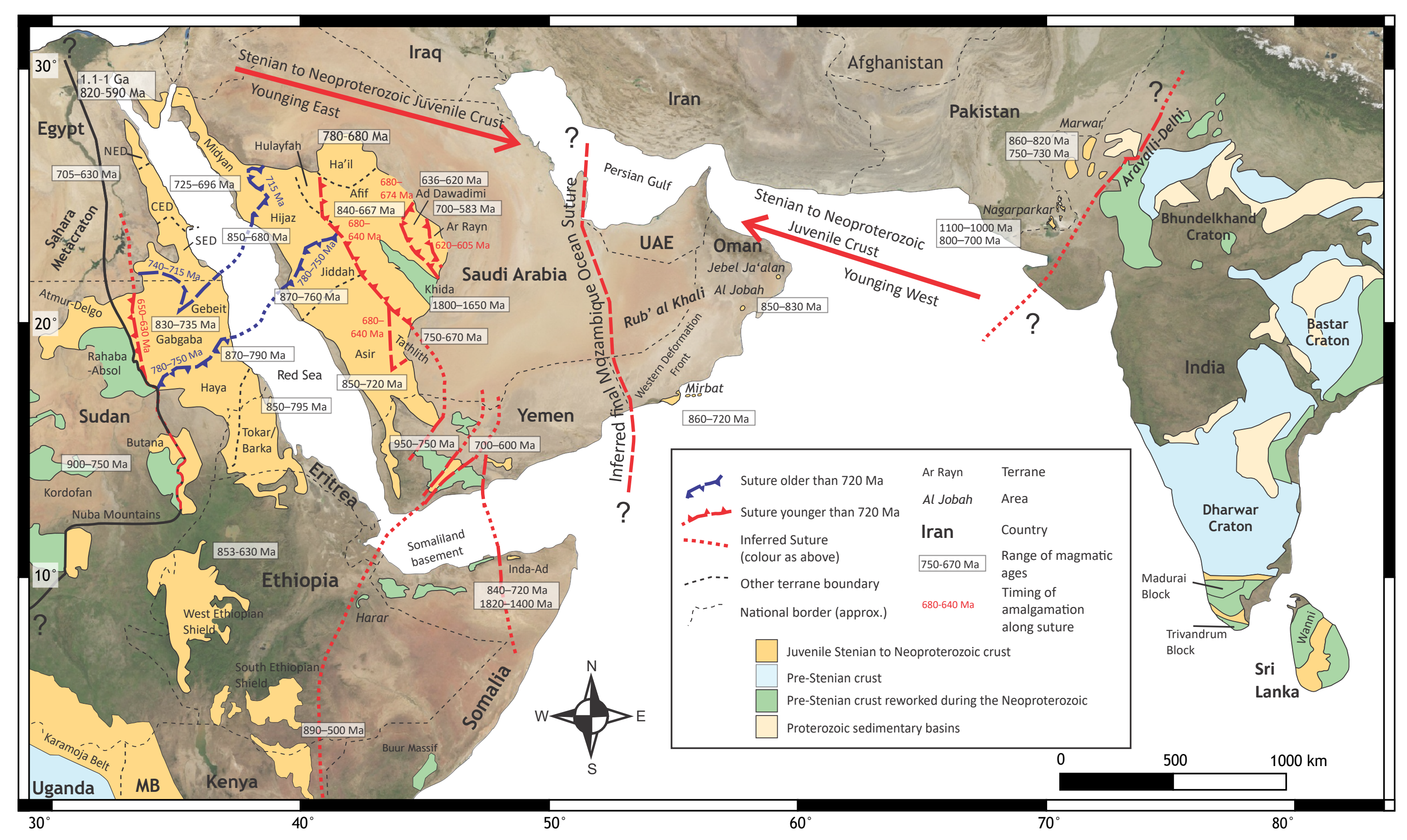



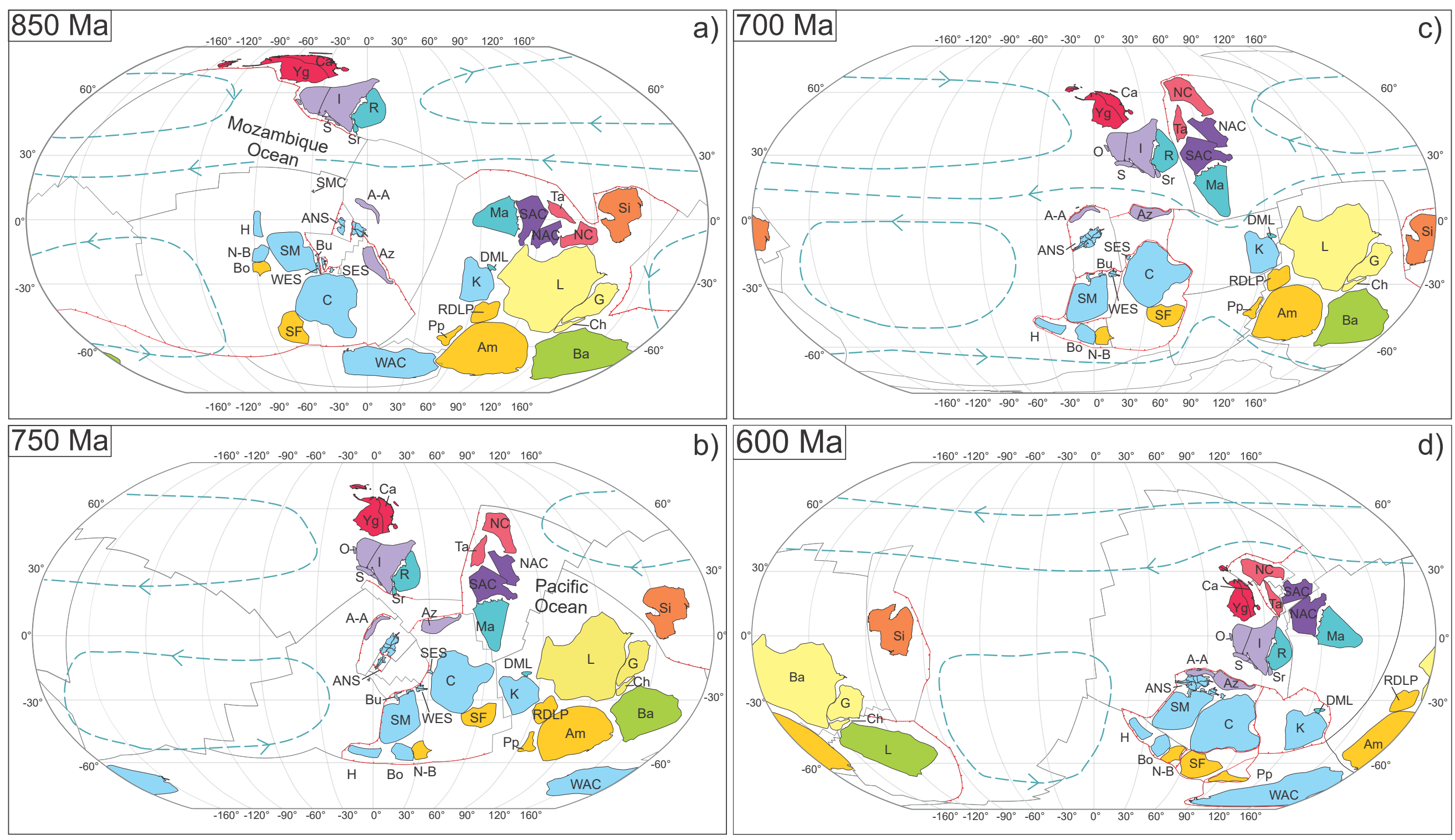

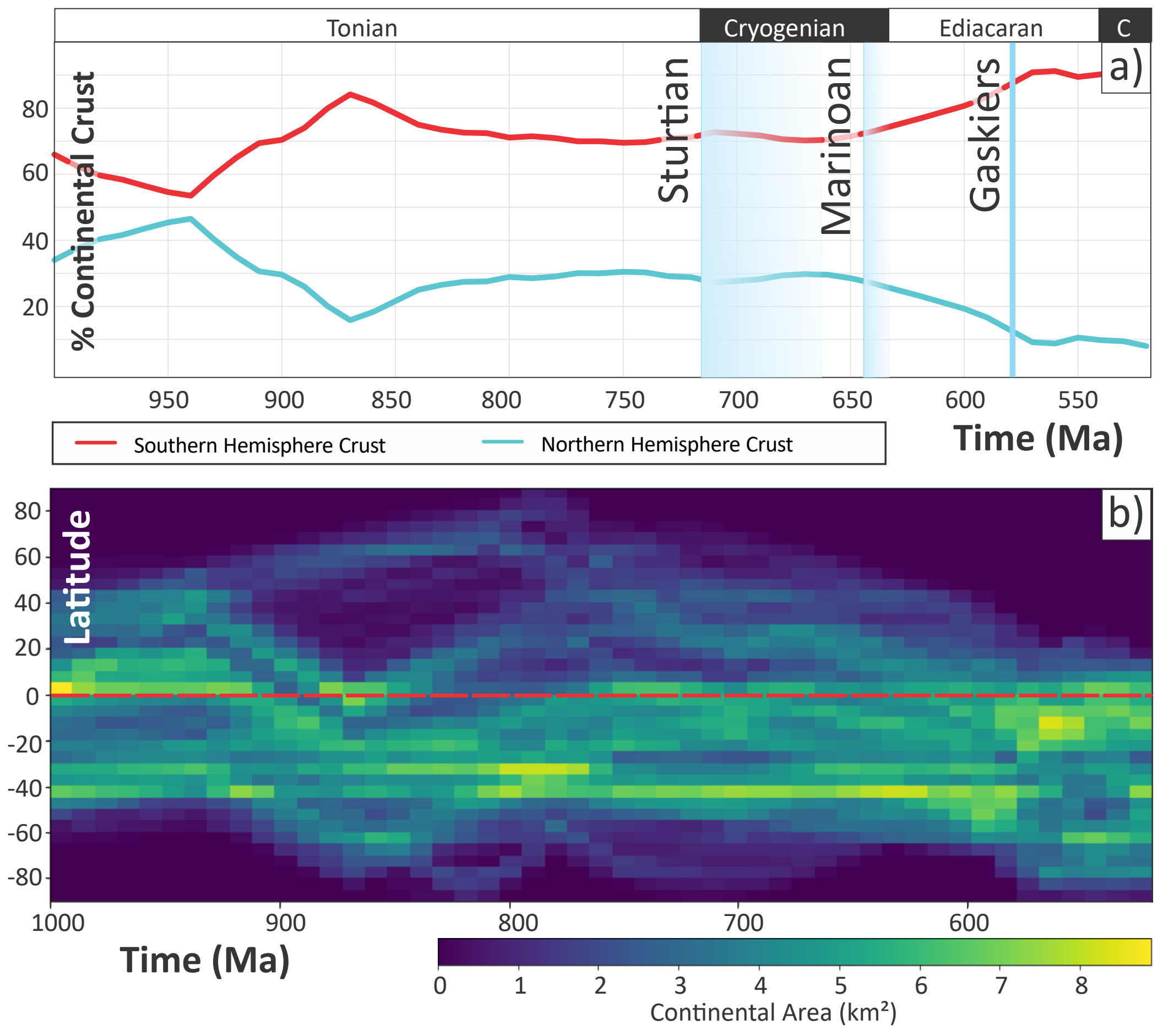